IES

29,1

50

Received 17 September 2020 Revised 16 January 2021 Accepted 16 May 2021

\section{Islamic equities and COVID-19 pandemic: measuring Islamic stock indices correlation and volatility in period of crisis}

\author{
Shafiu Ibrahim Abdullahi \\ SPS, Economic Unit, Sule Lamido University, Kafin Hausa, Nigeria and \\ Department of Economics, Bayero University, Kano, Nigeria
}

\begin{abstract}
Purpose - The purpose of the study is to measure cross-country stock market correlation and volatility transmission during the global coronavirus disease 2019 (COVID-19) pandemic. The paper traces trajectory of Islamic equity investments in order to get insights on the behavior of the markets during the crisis.

Design/methodology/approach - The paper uses generalized method of moments (GMM), autoregressive distributed lag (ARDL) and multivariate GARCH (MGARCH) models for analysis of dynamic causality, stock market cointegration, correlation and volatility transmission between Islamic stock indices.

Findings - The result of normal correlation analysis on the share indices show the markets move together. The result of ARDL cointegration test shows the markets returns are cointegrated as a group. To further make sense of the data; the indices were grouped into four different categories, then cointegration tests were conducted. The results of the analysis show that the subgroups are cointegrated except the low COVID-19 subgroup. Based on MGARCH findings, the possibility of volatility transmission between markets during the crisis is high. The market returns indices show the usual herd mentality common during the period of crisis. Originality/value - Unlike other works in this area, this paper attempt to trace the trajectory of Islamic equity investment in order to get relevant insights and arrives at appropriate ways of responding to the crisis.
\end{abstract}

Keywords Islamic index, Islamic finance, International finance, Stock exchange, Cross-country correlation, ARDL, MGARCH, GMM

Paper type Research paper

\section{Introduction}

The recent devastating impacts of coronavirus disease 2019 (COVID-19) on humans and their environment have been felt worldwide irrespective of the sector. The COVID-19 pandemic has affected the economy, politics, social interactions, religious rites and, above all, health. The COVID-19 impact has been categorized by many analysts as more devastating to the world economy than the last Great Recession of 2008/9. At the economic and finance levels, the equity markets have been seriously affected like all previous crises of this magnitude; the appropriate word to describe the situation is devastation. In Europe and the US, daily indices were reported to decline continuously during the peaks of the crisis. Like the COVID-19 pandemic itself, the financial contagion caused by it has spread from one corner of the world to another, affecting the global equity market. Several empirical works have assessed the nature and impact of the crisis on the global equity markets. Just like its conventional counterpart, the Islamic financial industry is also affected by this crisis. Global rating

\section{JEL Classification - F3, F6, G2. KAUJIE Classification - I73, I75}

(C) Shafiu Ibrahim Abdullahi. Published in Islamic Economic Studies. Published by Emerald Publishing Limited. This article is published under the Creative Commons Attribution (CC BY 4.0) licence. Anyone may reproduce, distribute, translate and create derivative works of this article (for both commercial and non-commercial purposes), subject to full attribution to the original publication and authors. The full terms of this licence may be seen at http://creativecommons.org/licences/by/4.0/ legalcode 
agencies such as S\&P have forecast the Islamic finance industry to slow down to a singledigit growth from double-digit growth in the previous years. S\&P also predicted a recession in the major Islamic finance markets in 2020 and a mild recovery in 2021 (S\&P, 2020). Many studies have shown that the Islamic equity index had outperformed its conventional counterparts during the COVID-19 crisis (Ashraf et al., 2020; Ahmed, 2020). Yet other studies such as that of Yarovaya et al. (2020) found that spillover effects from conventional to Islamic stock index become stronger during the COVID-19 pandemic.

In Pakistan, the stock market, which falls under the developing stock markets category, Islamic equities and COVID-19 pandemic suffered mild impacts of COVID-19 on the stock index. This feature has been associated with restrictions put in place by the government during the period (Waheed et al., 2020; Ahmed, 2020). But this phenomenon contradicted the conditions of developed stock markets such as the US, where the COVID-19 pandemic affected the markets significantly (Chowdhury and Zoynulabedin, 2020). In their paper on multidimensional financial immunity to the COVID-19 pandemic, Zaremba et al. (2020) found that markets in countries with low unemployment rates performed better during the crisis than those with high unemployment. These pieces of evidence are preliminary insights into the nature of the responses of the global equity markets to the COVID-19 crisis. Given the unique nature of Islamic finance, the current industrial development and the market's response during the previous global financial crisis when it was relatively less mature, scholars and practitioners are interested in knowing how Islamic equities responded to the crisis. Islamic finance in itself had a tumultuous and challenging history in the modern period. Should the financial catastrophe caused by COVID-19 be categorized as contagion? According to Abdullahi (2019a, b), contagion is widely viewed in the field of international finance as a significant increase in cross-market linkages during a crisis. Based on the findings of the recent studies, the COVID-19-induced equity crisis should be categorized as financial contagion.

The stock indices used for this work were established following Islamic stock screening criteria, otherwise known as Shariah index; they are financial times stock exchange (FTSE) Shariah indices and Dow Jones Islamic Market indices (DJIMIs). The countries where these indices are used are Malaysia, Nigeria, Canada, Thailand, USA EU, India, China, Japan and Pakistan. These nations were selected to provide geographical spread between developed and emerging economies, high COVID-19 and low COVID-19 countries, Muslim majority and nonMuslim majority countries, and FTSE and Dow Jones indices. The study period ranges from January 1, 2020 to August 17, 2020 to coincide with the COVID-19 pandemic period. The econometric methodologies used for the study are generalized method of moments (GMM), ARDL and MGARCH models. Each model has its purpose and uses: GMM is used to measure dynamic causality, ARDL measures cointegration and MGARCH measures volatility transmission between markets. This study aims not to make a direct comparison between different Shariah indices or between Islamic and conventional indices. The focus of the paper is on finding out how the different indices in the study responded to the crisis during the study period. The correlation and cointegration methods used in the study are not used for direct comparison; they are used to find out the level of comovements and linkages between the studied markets. Thus, the study is not a direct comparison with conventional indices (such as showing both indices side by side); rather, the study measures Islamic indices' response to the crisis. Related studies have measured the responses of conventional indices during the period; these include works of Yarovaya et al. (2020) and Chowdhury and Zoynulabedin (2020). The paper asks the question: does herd behavior affected Islamic stock indices? The study finds out the level of linkages among these Islamic stock indices and whether they are correlated during the crisis period.

\section{Related empirical literature on Islamic stock indices}

Many works have treated the issues of volatility linkage and portfolio diversification of Islamic stock indices. Akhtar et al. (2013), in their study, find volatility linkages to be weak in 
IES

29,1

Islamic markets compared to non-Islamic markets due to a smaller set of common information and lower cross-market hedging activity in Islamic markets. This feature suggested that the Islamic assets might be less contaminated by the global crisis during turbulent times than conventional assets. Yusof and Majid (2007) attempted to establish a possible link between volatilities in monetary policies with the volatility of stock returns in conventional and Islamic stocks in Malaysia. The findings show that the interest rate is insignificant in determining volatilities in an Islamic stock market, which is in line with the fundamentals of Islamic finance that interest rate is not a significant variable in explaining stock market volatility. A different study by Bhatt and Sultan (2012) tried to find out whether the feature of Islamic stocks being lower-leveraged made them less sensitive to leveraged risk compared to conventional socially responsible stocks. They found that the leverage risk factor performed consistently across firms, and the impact of Islamic stock is pronounced during the financial crisis of 2008/9. But they also found that the Shariah index was sensitive to leverage factor just like any conventional index. The academic work by Dewandaru $\mathrm{et} \mathrm{al}$. (2014) analyzed and compared the impact of macroeconomic factors on Islamic and conventional equity prices. The findings show that Islamic indices were more connected to the real sector because of the focus of Islamic finance on the real economy. Industrial production has more impact on the Islamic index than conventional ones.

In contrast, changes in short-term interest rate, money supply and consumer price index have milder effects on the Islamic stock index. Thus, the findings signified the relative stability of Islamic indices during economic shocks. At the same time, Arshad and Rizvi (2013) attempted to find out how business cycles affect the volatility of Islamic and conventional stock indices and answer whether Islamic stock indices are more stable during periods of financial recession than conventional ones. The analysis revealed that Islamic indices followed a similar pattern as conventional indices. Thus, they concluded that Islamic indices appeared to be more volatile during economic downturns and less volatile during the growth phase of the business cycle.

Bahlous and Yus of (2014) studied diversification benefits existing between Islamic indices around the world. The results of the long-run analysis showed that substantial diversification benefits existed among Middle East and North Africa (MENA), Asia-Pacific and North American indices. However, European and North American funds were found to be cointegrated in the long run, hence, minimizing diversification benefits. The short-run analysis indicated significant diversification benefits between the different regional markets except for Europe and North America. In another study, Rizvi and Arshad (2014) investigated the claims that the Islamic stock market was a safer alternative for investment during the financial crisis by utilizing MGARCH dynamic conditional correlation (DCC) to understand the dynamic correlations and volatilities of Islamic indices. They proved the decoupling effect of Islamic indices and the reduction in conditional correlations against global indices during the financial crisis. The findings show low correlations between Islamic and conventional stock indices during the time of crisis. Miniaoui et al. (2015) examined the performance of Islamic and conventional indices in Gulf Cooperation Council (GCC) countries of the Middle East in the wake of the financial crisis of 2008 using the GARCH approach. The estimated results were mixed. They revealed that the financial crisis caused volatility in some GCC markets (Kuwait, Bahrain and the United Arab Emirates), but its impact on the remaining GCC markets (Saudi Arabia, Oman and Qatar) and the Islamic index was not significant. They concluded that the GCC Islamic index exhibited similar attributes as the conventional indices in the analysis periods. A different empirical work by Saâdaoui et al. (2017) used wavelets analysis (considered a nonclassical econometric technique) to investigate the dynamic relationship between conventional and Islamic stock markets with the main aim of finding local microscopic signs of convergence or divergence. Their findings show the sensibility of Islamic stock returns to the global financial crisis is different than conventional 
stock returns across markets and time scales. The results of the analysis demonstrated strong dependence between conventional and Islamic indices at a lower frequency.

vSaiti et al. (2014) investigated whether Islamic stock indices provided better diversification benefits relative to conventional indices using the dynamic multivariate GARCHapproach. The focus of the study was US investors, with a view to helping diversify their portfolios by hedging unforeseen risks in the market. Their findings show that the purely Islamic stock indices did not provide more diversification benefits than their conventional counterparts. But there were regional diversification benefits; in particular, the results show Islamic countries provide better diversification advantages (compared to the Far East countries) to the US investors. Another work by El Khamlichi et al. (2014) explored the efficiency of Islamic indices and their potential for portfolio diversification compared to conventional indices. They explored whether the indices were cointegrated or not. The findings show that Islamic indices of Dow Jones and S\&P have no cointegrating relations with their respective benchmarks, which suggests the existence of long-run diversification opportunities. A similar work by Akbar and Barkely (2015) compared the performance of the DJIMI against the Wilshire 5000 (W5000), FTSE All-Share Index and Shanghai Stock Exchange Composite Index. They found no long-run cointegration between DJIMI and the studied indices. It also shows a lower level of volatility relative to the other indices. Majid and Kassim (2010) studied integration between major Islamic stock indices using ARDL, vector error correction model (VECM) and GMM. They wanted to determine whether investors could diversify their Shariah stock holdings without including conventional stocks. The paper found integration along regional and economic development lines. Hammoudeh et al. (2014), using a copula approach, show that the Islamic index exhibited significant dependence with conventional indices. Phan and Narayan (2020) argued that during the COVID-19 pandemic, markets around the world overreacted during the COVID-19 pandemic. As more information became available and people understood the ramifications more broadly, the markets corrected themselves.

\section{Data and methodology}

Stock index data were selected from FTSE Shariah indices and DJIMIs for sampled Islamic indices in the following places: Canada (Dow Jones), Hong Kong, China (Dow Jones), Europe (Dow Jones), India (Dow Jones), Japan (Dow Jones), USA (FTSE), Pakistan (FTSE), Malaysia (FTSE), Nigeria (NSE Lotus) and Thailand (FTSE). The index sampled ranges from January 1, 2020 to August 17, 2020 to coincide with the COVID-19 pandemic period. Daily data have the advantage of indicating daily changes in the stock market, which is how the financial crisis originated. Most market participants observe the market daily. These indices were selected to provide a fair representation of the main global Islamic share indices worldwide. Some are located in developed countries (the USA, Canada, Japan, Europe and Hong Kong), and others in emerging economies (Malaysia, Thailand, India, Pakistan and Nigeria). They are also divided into Muslim majority countries (Malaysia, Pakistan and Nigeria) and nonMuslim majority countries (the USA, Japan, Canada, India, Europe, Hong Kong and Thailand). All the share indices are daily price indices that comprise about 162 days' indices; they were accessed from ng.investing.com. ADF tests were conducted to test the presence of a unit root in different data levels. For the GARCH analysis, the daily index data were converted into daily returns using the formula below:

$$
y_{t}=100 \log \left[\frac{z_{t}}{z_{t-1}}\right]
$$

where $Y_{t}$-stock return in the current period; $Z_{t}-$ current period; $Z_{t-1}-$ previous period.

An empirical work of this nature requires a relevant econometric procedure to produce reliable results. Because of this, econometric models were selected for testing our research 
IES

29,1

\section{4}

hypothesis that Islamic stock indices followed herd mentality during the crisis. The methods of data analysis are GMM, ARDL and MGARCH.

Generalized method of moments (GMM)

GMM is recognized as a popular econometric model for financial time series analysis. It is very flexible and nests many traditional econometric models as special cases, and it does not require distributional assumptions. It is suitable for the estimation of short- and long-run relationships between variables. As with other instrumental variable estimators, for the GMM estimator to be identified, there must be at least as many instruments as there are parameters in the model. In models where there are the same numbers of instruments as parameters, the value of the optimized objective function is zero. If there are more instruments than parameters, the value of the optimized objective function will be greater than zero (Pindyck and Rubinfeld, 1998; Stock et al., 2002). Lags of explanatory variables were used as instrumental variables in this paper. This research decided to specify a GMM estimator because it allows the selection of weighting matrix to get a robust estimate. Hansen $e$ al. (2006) have shown that an asymptotically efficient or optimal GMM estimator can be obtained by choosing a weighting matrix so that it converges to the inverse of the long-run covariance matrix. The GMM tests the dynamic causal relationship among the markets during the period of the study.

\section{ARDL model}

The ARDL approach to cointegration was introduced by Pesaran et al. (1996). According to Fabozzi et al. (2006), the ARDL methodology regresses one variable on its past and on the present and past values of some other variables. In addition, the ARDL cointegration model captures the short- and long-run components of the model simultaneously. The ARDL model has wider application in testing stock market integration, such as Majid and Kassim (2010), who analyzed Islamic stock indices. It is suitable for capturing the level of cointegration between markets. The simple model without the error correction representation is as follows:

$$
\begin{aligned}
& \mathrm{Mal}_{t}=\beta_{1}+\beta_{2} \mathrm{Nig}_{t}+\beta_{3} \mathrm{Pak}_{t}+\beta_{4} \mathrm{Tha}_{t}+\beta_{5} \mathrm{USA}_{t}+\beta_{6} \mathrm{Jap}_{t}+\beta_{7} \operatorname{Ind}_{t}+\beta_{8} \text { Hon }_{t} \\
& +\beta_{9} \operatorname{Eur}_{t}+\beta_{10} \operatorname{Can}_{t}+\varepsilon_{t} \\
& \mathrm{Pak}_{t}=\beta_{1}+\beta_{2} \mathrm{Nig}_{t}+\beta_{3} \mathrm{Mal}_{t}+\beta_{4} \mathrm{Tha}_{t}+\beta_{5} \mathrm{USA}_{t}+\beta_{6} \mathrm{Jap}_{t}+\beta_{7} \operatorname{Ind}_{t}+\beta_{8} \mathrm{Hon}_{t} \\
& +\beta_{9} \operatorname{Eur}_{t}+\beta_{10} \operatorname{Can}_{t}+\varepsilon_{t} \\
& \mathrm{Nig}_{t}=\beta_{1}+\beta_{2} \mathrm{Mal}_{t}+\beta_{3} \mathrm{Pak}_{t}+\beta_{4} \mathrm{Tha}_{t}+\beta_{5} \mathrm{USA}_{t}+\beta_{6} \mathrm{Jap}_{t}+\beta_{7} \operatorname{Ind}_{t}+\beta_{8} \text { Hon }_{t} \\
& +\beta_{9} \operatorname{Eur}_{t}+\beta_{10} \operatorname{Can}_{t}+\varepsilon_{t} \\
& \mathrm{Can}_{t}=\beta_{1}+\beta_{2} \mathrm{Nig}_{t}+\beta_{3} \mathrm{Pak}_{t}+\beta_{4} \mathrm{Tha}_{t}+\beta_{5} \mathrm{USA}_{t}+\beta_{6} \mathrm{Jap}_{t}+\beta_{7} \operatorname{Ind}_{t}+\beta_{8} \mathrm{Hon}_{t} \\
& +\beta_{9} \operatorname{Eur}_{t}+\beta_{10} \mathrm{Mal}_{t}+\varepsilon_{t} \\
& \text { Eur }_{t}=\beta_{1}+\beta_{2} \mathrm{Nig}_{t}+\beta_{3} \mathrm{Pak}_{t}+\beta_{4} \mathrm{Tha}_{t}+\beta_{5} \mathrm{USA}_{t}+\beta_{6} \mathrm{Jap}_{t}+\beta_{7} \operatorname{Ind}_{t}+\beta_{8} \mathrm{Hon}_{t} \\
& +\beta_{9} \mathrm{Mal}_{t}+\beta_{10} \mathrm{Can}_{t}+\varepsilon_{t} \\
& \operatorname{Hon}_{t}=\beta_{1}+\beta_{2} \mathrm{Nig}_{t}+\beta_{3} \mathrm{Pak}_{t}+\beta_{4} \mathrm{Tha}_{t}+\beta_{5} \mathrm{USA}_{t}+\beta_{6} \mathrm{Jap}_{t}+\beta_{7} \operatorname{Ind}_{t}+\beta_{8} \mathrm{Mal}_{t} \\
& +\beta_{9} \operatorname{Eur}_{t}+\beta_{10} \operatorname{Can}_{t}+\epsilon_{t}
\end{aligned}
$$




$$
\begin{aligned}
\operatorname{Ind}_{t}= & \beta_{1}+\beta_{2} \mathrm{Nig}_{t}+\beta_{3} \mathrm{Pak}_{t}+\beta_{4} \mathrm{Tha}_{t}+\beta_{5} \mathrm{USA}_{t}+\beta_{6} \mathrm{Jap}_{t}+\beta_{7} \mathrm{Mal}_{t}+\beta_{8} \mathrm{Hon}_{t} \\
& +\beta_{9} \mathrm{Eur}_{t}+\beta_{10} \mathrm{Can}_{t}+\varepsilon_{t} \\
\mathrm{Jap}_{t}= & \beta_{1}+\beta_{2} \mathrm{Nig}_{t}+\beta_{3} \mathrm{Pak}_{t}+\beta_{4} \mathrm{Tha}_{t}+\beta_{5} \mathrm{USA}_{t}+\beta_{6} \mathrm{Mal}_{t}+\beta_{7} \mathrm{Ind}_{t}+\beta_{8} \mathrm{Hon}_{t} \\
& +\beta_{9} \mathrm{Eur}_{t}+\beta_{10} \mathrm{Can}_{t}+\varepsilon_{t} \\
\mathrm{Tha}_{t}= & \beta_{1}+\beta_{2} \mathrm{Nig}_{t}+\beta_{3} \mathrm{Pak}_{t}+\beta_{4} \mathrm{Mal}_{t}+\beta_{5} \mathrm{USA}_{t}+\beta_{6} \mathrm{Jap}_{t}+\beta_{7} \operatorname{Ind}_{t}+\beta_{8} \mathrm{Hon}_{t} \\
& +\beta_{9} \mathrm{Eur}_{t}+\beta_{10} \mathrm{Can}_{t}+\varepsilon_{t} \\
\mathrm{USA}_{t}= & \beta_{1}+\beta_{2} \mathrm{Nig}_{t}+\beta_{3} \mathrm{Pak}_{t}+\beta_{4} \mathrm{Tha}_{t}+\beta_{5} \mathrm{Mal}_{t}+\beta_{6} \mathrm{Jap}_{t}+\beta_{7} \operatorname{Ind}_{t}+\beta_{8} \operatorname{Hon}_{t} \\
& +\beta_{9} \operatorname{Eur}_{t}+\beta_{10} \mathrm{Can}_{t}+\varepsilon_{t}
\end{aligned}
$$

The joint hypotheses to be tested for bound testing are as follows:

$$
\begin{gathered}
H_{0}: \beta_{2}=\beta_{3}=\beta_{4}=\beta_{5}=\beta_{6}=\beta_{7}=\beta_{8}=\beta_{9}=\beta_{10}=0 \\
H_{1}: \beta_{2} \neq 0, i=1,2, \ldots, 9
\end{gathered}
$$

$F$-test is used to test for cointegration through testing for significance of the lagged levels of the variables. Our null hypothesis of no cointegration is $H_{0}: k_{1}=k_{2}=k_{i}=0$. It is tested against the alternative of at least one non-zero result, i.e. $H_{1}: k_{1} \neq 0$ or $k_{2} \neq 0$ or $k_{i} \neq 0$. The calculated $F$-statistics is compared with sets of critical values. If the $F$-statistic exceeds the upper bound level, the null hypothesis is rejected, which indicates cointegration. On the other hand, if the $F$-statistics falls below the lower bound level, the null hypothesis cannot be rejected, supporting the nonexistence of cointegration. However, if it falls within the upper and lower bounds, the result is inconclusive (Pesaran et al., 1996). The lag length selection criteria adopted is Akaike information criteria.

\section{MGARCH models}

The diagonal BEKK model is originally in the form:

$$
H_{t}=\varnothing \varnothing^{\prime}+A \varepsilon_{t-1} \varepsilon_{t-1}^{\prime} A^{\prime}+B H_{t-1} B^{\prime}
$$

The BEKK model belonging to the multivariate volatilities model has many important financial applications. This diagonal BEKK model is identical to the diagonal VECH model, where the coefficient matrices are rank-one matrix. According to Evans and McMillan (2006), parsimonious parameterization can be obtained by imposing a diagonal restriction on the multivariate parameter matrices. Each variance and covariance element depends only upon its past values. The model allows for dynamic dependence between volatility in time series data. For this analysis, we employ the $\operatorname{BEKK}(1,1)$ model.

\section{Results and analysis}

Figure 1 shows how the share price indices trend; during the period, the Islamic share indices trended together irrespective of the location of the index, whether it is located in a developing country or developed one. The indices started falling and then at some point started rising almost in coordination with one another. The period of the lowest falls in share prices coincided with the peak period in the crisis. When cases of the COVID-19 infection began to fall, and the economies of the world started to open up gradually, all the share indices began to move up. 
IES

29,1

56
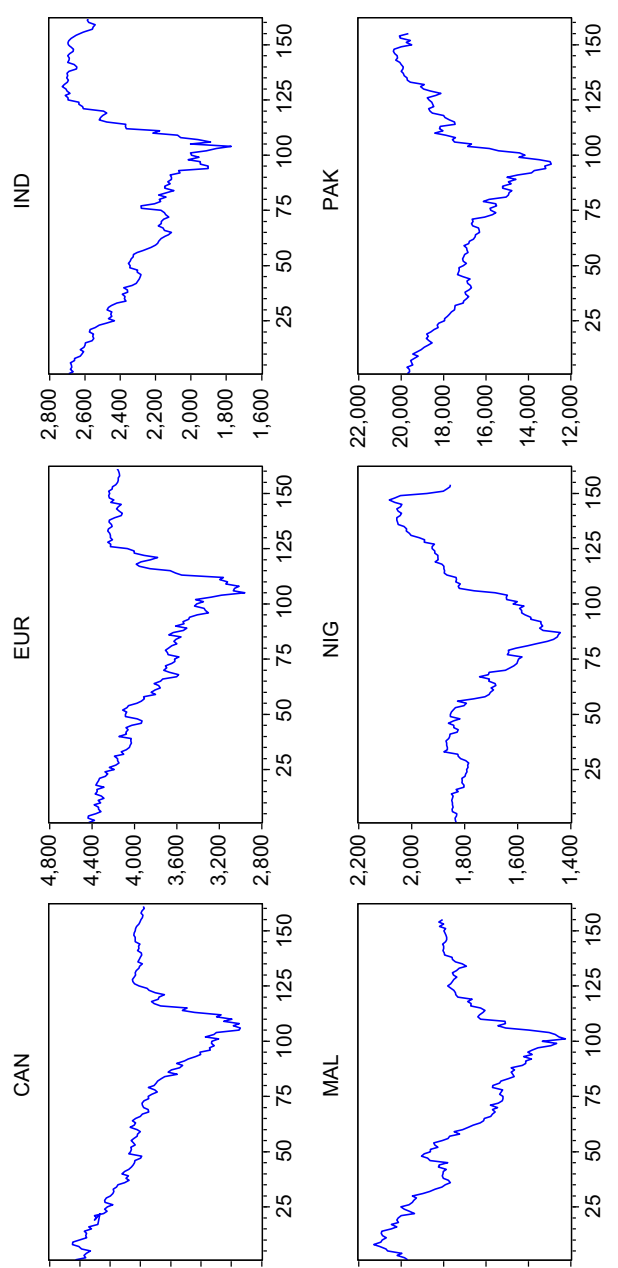

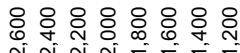
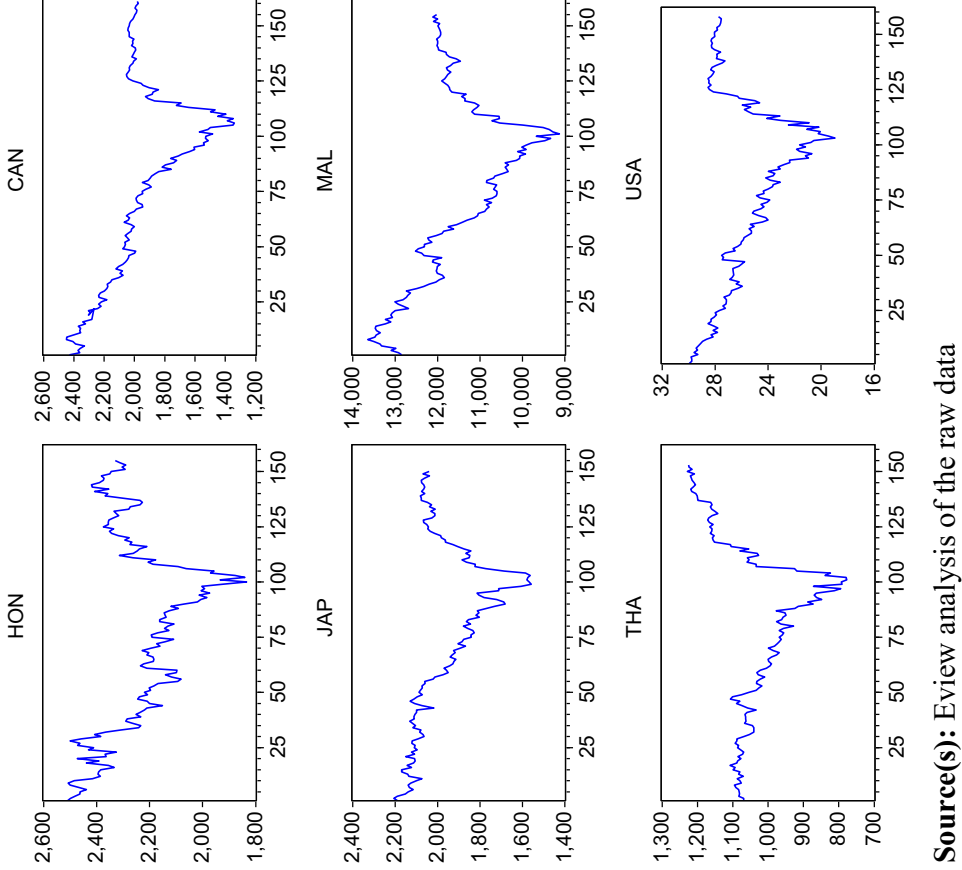

Figure 1.

Islamic share indices trending pattern 
GMM results

The GMM model tests the dynamic causal relationship among the various markets in the study. When a particular market is either directly or indirectly triggered by a different market, it means movements in the first market can affect movements in the second market, establishing a kind of linkage between them. Thus, the GMM dynamic analysis shows that the Pakistan index was caused (i.e. influenced) by Nigeria, Malaysia, Japan, Europe and Canada markets. The Malaysian index was caused by Pakistan, Thailand, Japan and Hong Kong. The Nigerian index was caused by Pakistan, Japan, Europe and Canada. The Indian index was caused by Japan, the USA, Hong Kong and Canada. The Japan index was caused by Malaysia, Nigeria, Pakistan, Thailand and Canada. The European index was caused by Hong Kong, India, Pakistan and Canada. The Thailand index was caused by Pakistan, Malaysia, Japan and Canada. The USA index was not caused by any of the individual markets. The Canadian index was caused by Europe, Hong Kong, India and the USA. The Hong Kong index was caused by India, Europe and Canada. See Table 1 for the values of the coefficients and their signs.

\section{ARDL results}

With a study period of about seven and a half months, the paper is not interested in the longrun relationship between the share indices. Hence, the focus is on the short-run dynamics. The results of the ARDL bound testing on the share indices show that the indices of Japan and Europe are cointegrated with the rest of the indices in the portfolio during the period, while Malaysia, Nigeria and Canada are not cointegrated with the indices in the portfolio. But the results for the indices of Pakistan, the USA, Hong Kong, India and Thailand are inconclusive. The same tests conducted on market returns, not the share indices, show different results. The ARDL bound test run on the daily returns shows that the daily market returns are cointegrated. Thus, it precluded any diversification benefit during the period (see Table 2) .

Bivariate cointegration resulting from a host country index to a sister index shows Malaysia is cointegrated with Pakistan, Thailand and Japan. Pakistan is cointegrated with Nigeria and Japan; Nigeria is not cointegrated with any of the markets; Canada is cointegrated with India and the USA; Europe is cointegrated with India, Malaysia, Nigeria, Pakistan and the USA. Hong Kong is cointegrated with Nigeria, Pakistan and Canada; India is cointegrated with Thailand, the USA and Hong Kong; Japan is cointegrated with Malaysia, Nigeria, Pakistan, Thailand and Canada; Thailand is cointegrated with Pakistan, Malaysia and Japan; and the USA is cointegrated with India and Canada. Generally, under cointegration, markets (multiple portfolios) or individual indices (bivariate) share cointegration with one another, meaning that they have common stochastic trends. This phenomenon suggests that information from one market or individual index that trends with the other can be used to forecast the behavior and performance of different markets or indices.

The share return indices were grouped into categories like developed and emerging markets, high Covid-19 and low COVID-19 (as reported in https:/www.worldometers.info/ coronavirus/countries-where-coronavirus-has-spread), Muslim and non-Muslim, and FTSE and Dow Jones to further make sense of the data. Then cointegration tests were conducted within these groups to determine whether they are cointegrated or not during the study period. The analysis results show that all the groups are cointegrated (within their respective grouping) except the low COVID-19 group; see Table 3. The implication is that markets within these groups have more connectivity during the crisis than the greater sample.

\section{MGARCH results}

For the MGARCH analysis, daily return data were used. Figure 2 shows the graphical outline of the daily returns of all the indices in the study. It shows that returns volatility is highest

Islamic equities

and COVID-19 pandemic 
IES
29,1

58

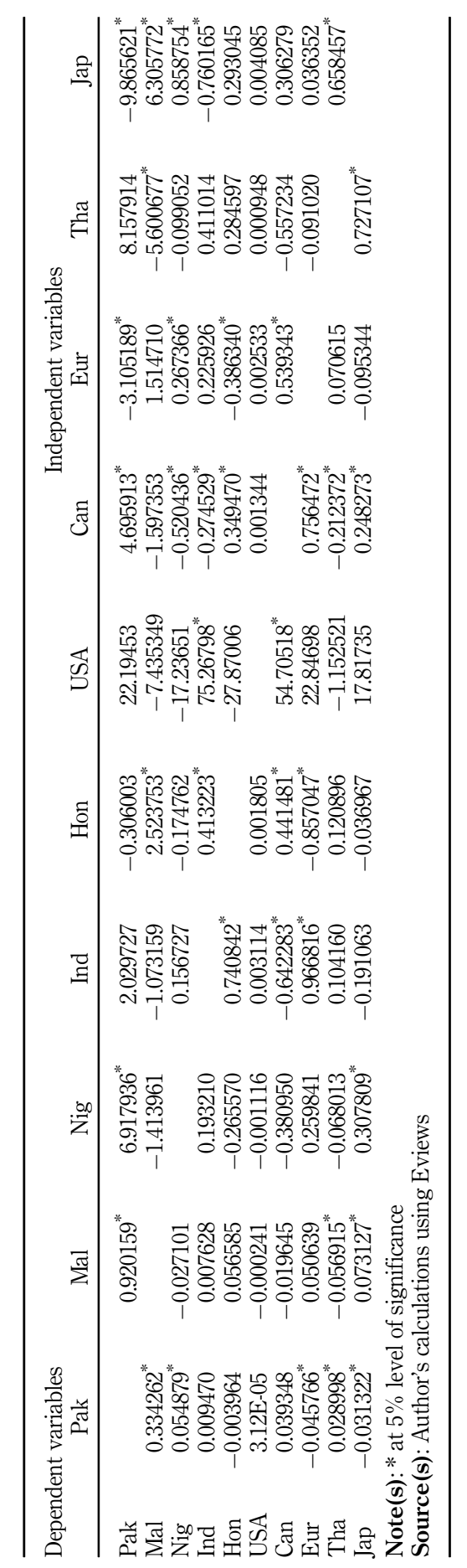

Table 1.

Analysis of dynamic causal relationship between the markets using the GMM model 


\begin{tabular}{llccr}
\hline Country/location & Share index & $F$-statistics (indices) & F-statistics (returns) & $\begin{array}{r}\text { Islamic equities } \\
\text { and COVID-19 }\end{array}$ \\
\hline 1. Malaysia & FTSE & 1.158894 & 24.37967 & pandemic \\
2. Pakistan & FTSE & 3.080466 & 5.795777 & \\
3. Nigeria & NSE-Lotus Islamic index & 0.980085 & 11.76968 & \\
4. Canada & Dow Jones & 1.542158 & 16.39155 & \\
5. Europe & Dow Jones & 4.486088 & 8.452713 & $\mathbf{5 9}$ \\
6. Hon Kong & Dow Jones & 3.183393 & 21.10642 & \\
7. India & Dow Jones & 3.592059 & 9.403599 & \\
8. Japan & Dow Jones & 4.185280 & 9.817141 & \\
9. Thailand & FTSE & 3.236223 & 9.020478 & Table 2. \\
10. USA & FTSE & 3.442735 & & Bounds F-test for \\
Note(s): The lower bound (2.04) and upper bound (2.08) at 5\% level of significance & & & \\
Source(s): Author's calculation using Eviews & & &
\end{tabular}

\begin{tabular}{|c|c|c|c|c|c|}
\hline \multirow[b]{2}{*}{$\begin{array}{l}\text { Economic } \\
\text { grouping }\end{array}$} & \multicolumn{4}{|c|}{ Cointegration level within the various grouping } & \\
\hline & $\begin{array}{l}\text { Developed } \\
\text { USA, Jap, Eur, } \\
\text { Can, Hon }\end{array}$ & $\begin{array}{l}\text { F-stat. } 18.28767 \\
\text { Upper bound (5\%) } \\
3.49 \\
\text { Verdict: there is } \\
\text { cointegration }\end{array}$ & $\begin{array}{l}\text { Emerging } \\
\text { Pak, Nig, Tha, Mal, } \\
\text { Ind }\end{array}$ & $\begin{array}{l}\text { F-stat. } 7.737067 \\
\text { Upper bound (5\%) } \\
3.49 \\
\text { Verdict: there is } \\
\text { cointegration }\end{array}$ & \\
\hline COVID-19 & \multicolumn{2}{|c|}{ High COVID group } & \multirow{2}{*}{$\begin{array}{l}\text { Low COVID group } \\
\text { Pak, Nig, Mal, Can, } \\
\text { Hon, Jap, Tha }\end{array}$} & & \\
\hline intensity & USA, Eur, Ind & $\begin{array}{l}\text { F-stat. } 60.13915 \\
\text { Upper bound (5\%) } \\
3.87 \\
\text { Verdict: there is } \\
\text { cointegration }\end{array}$ & & $\begin{array}{l}\text { F-stat } \\
2.797282 \\
\text { Upper bound (5\%) } \\
3.28 \\
\text { Verdict: inconclusive }\end{array}$ & \\
\hline $\begin{array}{l}\text { Shariah index } \\
\text { provider }\end{array}$ & $\begin{array}{l}\text { FTSE } \\
\text { Mal, Pak, Tha, } \\
\text { USA, Nig }\end{array}$ & $\begin{array}{l}\text { F-stat. } 8.346783 \\
\text { Upper bound (5\%) } \\
3.49 \\
\text { Verdict: there is } \\
\text { cointegration }\end{array}$ & $\begin{array}{l}\text { Dow Jones } \\
\text { Can, Ind, Hon, Jap, } \\
\text { Eur }\end{array}$ & $\begin{array}{l}\text { F-stat } \\
12.09641 \\
\text { Upper bound (5\%) } \\
3.49 \\
\text { Verdict: there is } \\
\text { cointegration }\end{array}$ & \\
\hline $\begin{array}{l}\text { Religion base } \\
\text { grouping }\end{array}$ & $\begin{array}{l}\text { Muslim majority } \\
\text { Pak, Mal, Nig }\end{array}$ & $\begin{array}{l}\text { F-stat. } 15.64636 \\
\text { Upper bound (5\%) } \\
3.87 \\
\text { Verdict: there is } \\
\text { cointegration }\end{array}$ & $\begin{array}{l}\text { Non-Muslim } \\
\text { USA, Jap, Eur, Can, } \\
\text { Hon, Tha, Ind }\end{array}$ & $\begin{array}{l}\text { F-stat } \\
22.63823 \\
\text { Upper bound (5\%) } \\
3.28 \\
\text { Verdict: there is } \\
\text { cointegration }\end{array}$ & \\
\hline Source(s): Au & r's computations & & & & Markets groupings \\
\hline
\end{tabular}

around March. As portfolio theory rightly predicted, there was comovement between the market returns during the crisis, unlike what was obtained during normal times. Table 4 provides the summary statistics of the return data. It shows that average daily returns are positive, although insignificant, except for the Thailand index, which is negative. The markets indicate a similar level of riskiness, as shown by their respective standard deviations. The negative skewness in the return indices implies that significant negative changes in market returns occur more often than positive changes. The excess kurtosis 
IES

29,1

60

Figure 2.

Stock indices returns

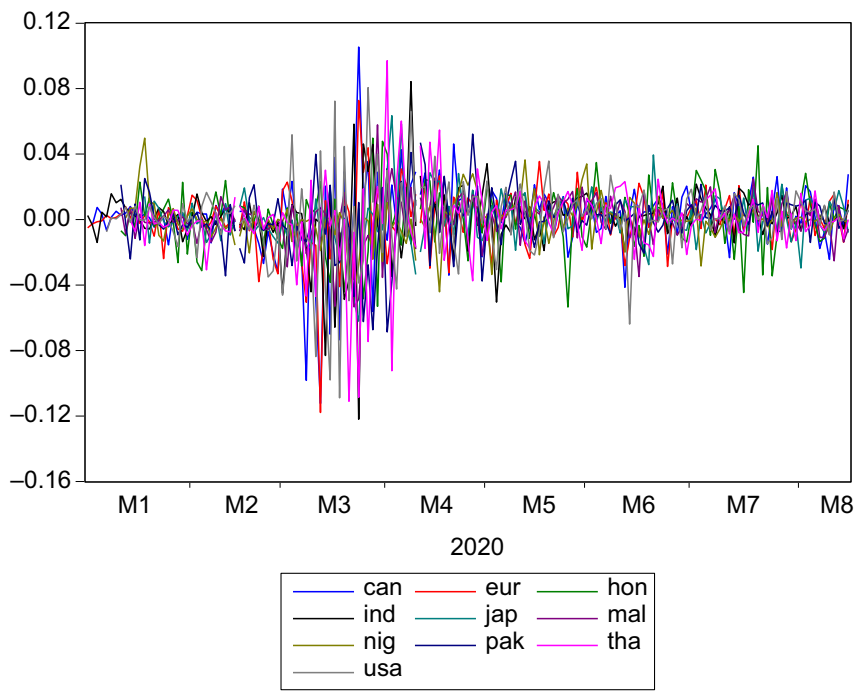

Source(s): Author's calculation using Eview

indicates that the stock market returns exhibit leptokurtosis, a well-known stylized fact in the finance literature. The huge Jarque-Bera statistics reject the null hypothesis of normal distribution for the series. This provides further evidence of the existence of GARCH effects.

The study uses the multivariate GARCH model to estimate the volatility and correlation of returns of the selected indices. The result of the diagonal BEKK $(1,1)$ with GARCH (1) coefficient and multivariate student's $t$ error distribution shows that volatility across the markets is widely distributed during the period. Bivariate correlations show that volatility correlations between the markets are relatively high between corresponding markets, as shown in Figure 3. Volatility correlation is widespread during the period. Unlike in a period of calm when volatility correlation is mainly in the positive territory and not widespread, volatility correlations here fluctuate between positive and negative regions and is a bit skewed toward the positive region. In addition, the markets look the same during the period, testimony to the long-held belief that markets behave in the same way during a crisis. On average, the volatility correlation is highest around March for the markets in the study.

The volatility transmission analysis shows a similar pattern of the response of Islamic indices during the COVID-19 pandemic like those found in conventional indices. This outcome may be due to the nature of the current crisis, which has impacted all sectors of economies (real and financial), unlike the previous crisis in 2008/9, which affected just the financial sector. Previous studies analyzing the impact of macroeconomic factors on Islamic and conventional equity prices have discovered that Islamic indices were more connected to the real sector because of the focus of Islamic finance on the real economy (Dewandaru et al., 2014). Thus, industrial production has more impact on the Islamic index than conventional. Hence, those expecting Islamic equities to respond to the same way they responded to the 2009 crisis might be wrong. Unlike the past financial sector-focused crisis (with leverage factors playing an important role), the current situation has affected the real economy more than the financial sector. Another work that goes along with this finding is that of Arshad and Rizvi (2013), who attempted to find out how business cycles affect the volatility of Islamic and conventional stock indices and answer whether Islamic stock indices are more stable during periods of financial recession than conventional. The analysis revealed that Islamic indices 


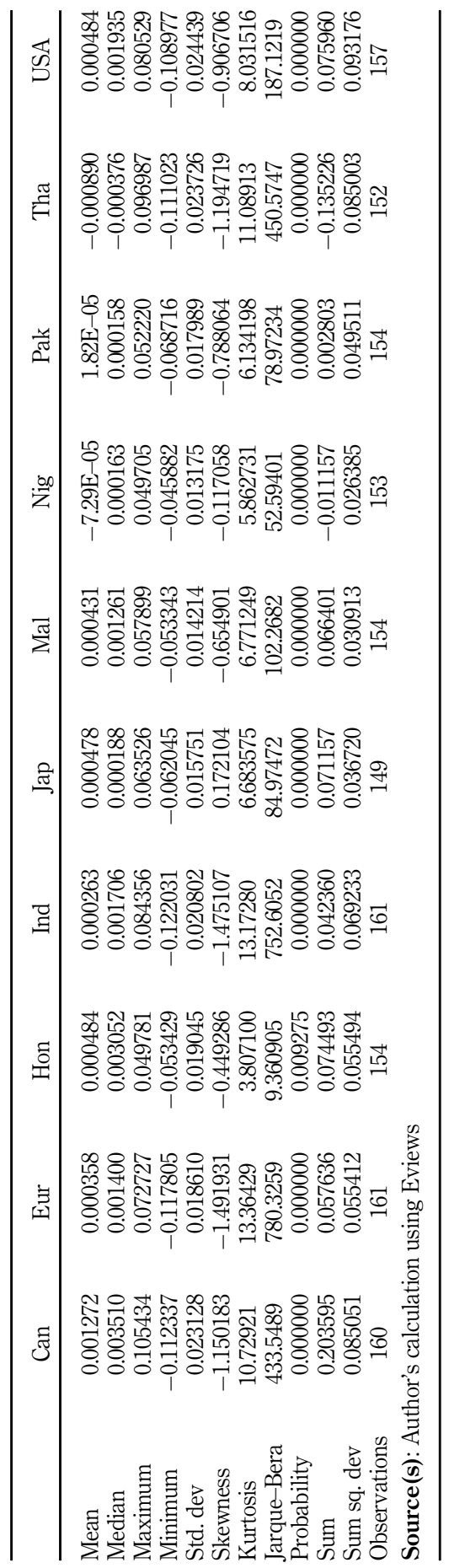

Islamic equities and COVID-19 pandemic

61

Table 4 Summary statistics of stock markets returns 
IES

29,1

62

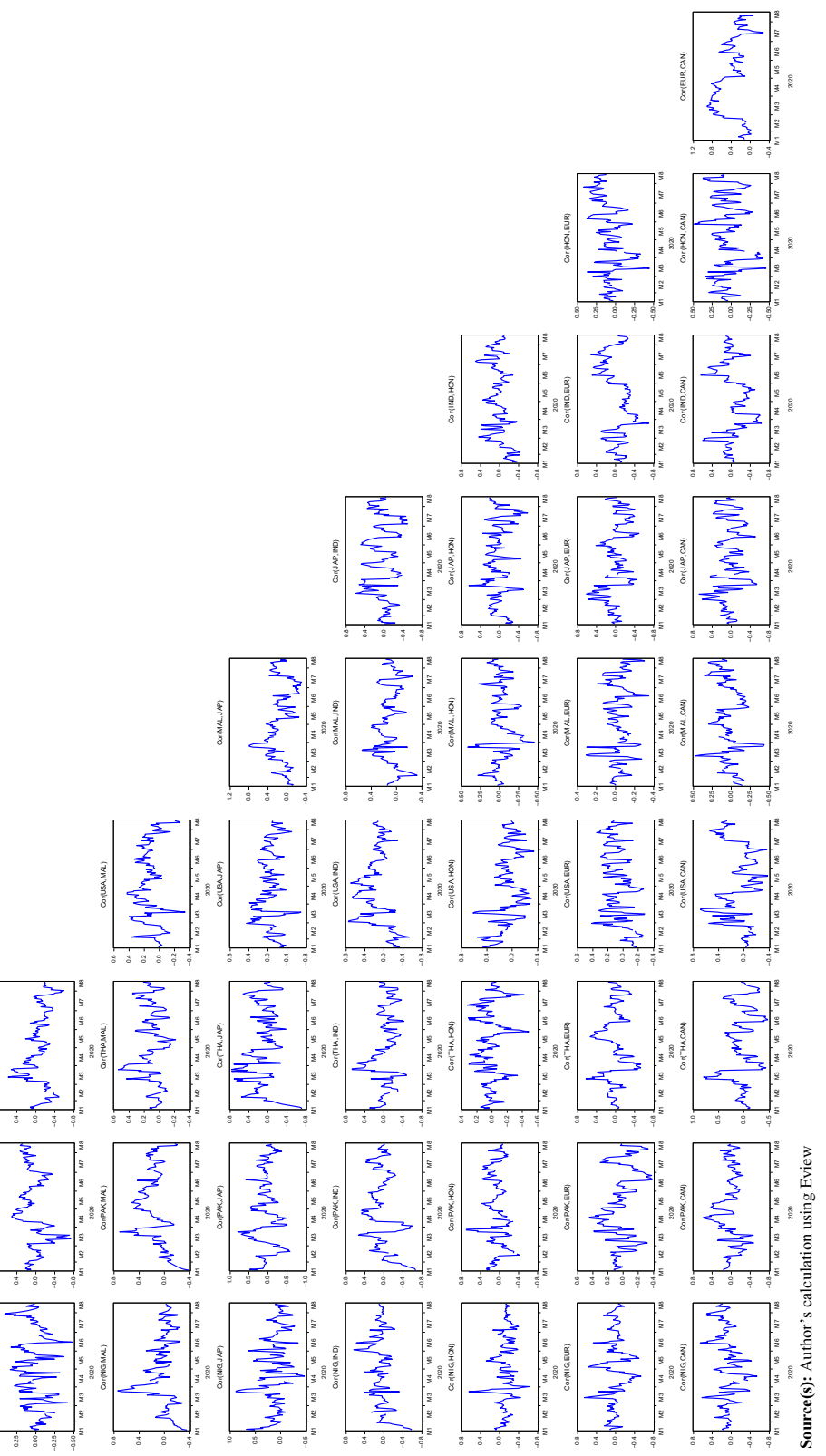

Figure 3.

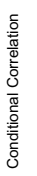

correlations between markets 
followed a similar pattern as that of conventional indices. This outcome led to the conclusion that Islamic indices appeared to be more volatile during economic downturns and less volatile during the growth phase of a business cycle.

Works that show a low correlation between Islamic and conventional indexes during a crisis, such as that of Rizvi and Arshad (2014), and Saâdaoui et al. (2017), were conducted using data with a time range that included the 2009 crisis, which was predominantly a financial sector crisis, unlike the all-encompassing COVID-19 pandemic. Works such as that of Miniaoui et al. (2015) on the responses of the Islamic index during the 2009 crisis show mixed results. Hammoudeh et al. (2014), using a copula approach, show that Islamic indices exhibited significant dependence on conventional indices. Other works such as Yarovaya et al. (2020) show that the spillovers between conventional and Islamic stock markets become stronger during the pandemic. Thus, the result found in this paper that Islamic indices joining the herd mentally just like their conventional counterparts have been predicted by previous works in this field.

\section{Implications}

Looking back at the performance of Islamic share indices during the crisis of 2008/9, understanding how indices perform during the COVID-19 crisis becomes relevant for recognizing the development of the Islamic finance industry. It will enable scholars, policymakers and investors in the field to improve the current structure and prepare the sector for future crises. It also may act as a pointer to the resilience of Islamic share indices vis-a-vis conventional indices or otherwise. The unique nature of Islamic markets regarding their screening criteria and other related factors make them differ from the larger conventional indices. But during crises, like financial contagion, markets do not follow a rational pattern. The high COVID-19 group in this study has shown cointegration while the low COVID-19 group has shown none; this might be due to the different levels of fear caused by the pandemic in these respective markets. Abbes and Trichilli (2015) found long-run equilibrium relationships among Islamic stock markets of similar economic grouping. But they were partially segmented for different economic groupings. In addition, these authors found that the level of integration and causality relations among Islamic stock markets tend to change over time, mainly during periods characterized by financial crises. However, the transmission of the crisis around the world may not solely be due to cross-market transmission. The crisis transmission may be partially due to the crisis's impact on domestic economies. The COVID-19 pandemic affected the real economies of the host nations, thereby affecting their stock markets since these markets have a substantial number of domestically located firms. The analysis results also show that returns from both FTSE and Dow Jones Islamic indices followed the same herd mentality underscoring any significant effect different screening criteria might have had on the performance of these indices. The finding is also in line with Ashrafa and Khawaja (2016), who found that Shariah screening standards were insignificant to evaluate return performance.

\section{Conclusion}

The results from the present study showed that (as with any unexpected news) Islamic markets overreact around March 2020 when the virus quickly spread around the world. As more information became available, governments put temporary measures in place, and people understood the ramifications, the markets began to correct themselves. The MGARCH analysis shows that the Islamic index response during the crisis is not different from a conventional index. They follow herd behavior and are affected by the crisis. Thus, the crisis in one Islamic share index can easily spread to other share indices. The main aim of the work 
IES

29,1

is to find out whether Islamic indices follow conventional herd behavior, whether volatility in other markets affects Islamic markets and whether Islamic markets are open to financial contagion. The answer to all is yes. All markets in the study were affected by the crisis in terms of volatility and linkage with other affected markets.

\section{References}

Abbes, M.B. and Trichilli, Y. (2015), "Islamic stock markets and potential diversification benefits", Borsa Istanbul Review, Vol. 15 No. 2, pp. 93-105.

Abdullahi, S.I. (2019a), "Measuring volatility linkage, clustering and sensitivity to external shocks in Nigeria stock index", International Journal of Financial Services Management, Vol. 9 No. 4, pp. 345-368.

Abdullahi, S.I. (2019b), "Risk management and corporate governance: an Islamic perspective", in Azid, T., Al Nodl, A.A. and Qureshi, M.A. (Eds), Research in Corporate and Shariah Governance in the Muslim World: Theory and Practice, Emerald Publishing Company, London.

Ahmed, S.Y. (2020), "Impact of COVID-19 on performance of Pakistan stock exchange", available at: https://ssrn.com/abstract $=3643316(27 / 8 / 2020)$.

Akbar, Z. and Barkely, D. (2015), "The performance of Islamic equity indexes global capital markets", Journal of Islamic Economics, Banking and Finance, Vol. 11 No. 1, pp. 71-92.

Akhtar, S.M., Jahromi, M., John, K. and Moise, C.E. (2013), "Intensity of volatility linkages in Islamic and conventional markets", AFA 2012 Chicago Meetings Paper, available at SSRN: http://ssrn. com/abstract $=1782220$ or http://dx.doi.org/10.2139/ssrn.1782220 (accessed 21 August 2020).

Arshad, S. and Rizvi, S.A. (2013), "Inferences between business cycles and stock markets: a comparative analysis of Islamic stock indices", available at: http://www.researchgate.net/ publication/279825534 (accessed 4 July 2019).

Ashraf, D., Rizwan, M.S. and Ahmad, G. (2020), "Islamic equity investments and the COVID-19 pandemic", available at: https://ssrn.com/abstract $=3611898$ (accessed 21 August 2020).

Ashrafa, D. and Khawaja, M. (2016), "Does the Shariah screening process matter? Evidence From Shariah-compliant portfolios", Journal of Economic Behavior and Organization, Vol. 132, pp. 77-92.

Bahlous, M. and Yusof, R.M. (2014), "International diversification among Islamic investments: is there any benefit”, Managerial Finance, Vol. 40 No. 6, pp. 613-633.

Bhatt, V. and Sultan, J. (2012), "Leverage risk, financial crisis, and stock returns: a comparison among Islamic, conventional, and socially responsible stocks", Islamic Economic Studies, Vol. 20 No. 1, pp. 87-143.

Chowdhury, E.K. and Zoynulabedin, M. (2020), "COVID-19 effects on the US stock index returns: an event study approach", available at: https://ssrn.com/abstract $=3611683$ (accessed 10 August 2020).

Dewandaru, G., Rizvi, S.A., Sarkar, K., Bacha, O. and Masih, M. (2014), "How do macroeconomic changes impact Islamic and conventional equity prices? Evidence from developed and emerging countries", MPRA Paper, No. 59587 available at: https:/mpra.ub.uni-muenchen.de/ 59587/ (accessed 15 September 2018).

El Khamlichi, A., Sarkar, K., Arouri, M. and Teulon, F. (2014), "Are Islamic equity indices more efficient than their conventional counterparts? Evidence from major global index families", The Journal of Applied Business Research, Vol. 30 No. 4, pp. 1137-1150.

Evans, T. and McMillan, D.G. (2006), "Financial Co-movement and correlation: evidence from 33 international stock market indices", International Journal of Banking, Accounting and Finance, Vol. 1 No. 3, pp. 215-241.

Fabozzi, F.J., Focardi, S.M., Focardi, S. and Kolm, P.N. (2006), Financial Modeling of the Equity Market: From CAPM to Co-integration, Wiley, Hoboken, NJ. 
Hammoudeh, S., Mensi, W., Reboredo, J.C. and Nguyen, D.K. (2014), "Dynamic dependence of the global Islamic equity index with global conventional equity market indices and risk factors", Pacific-Basin Finance Journal, Vol. 30, pp. 189-206, doi: 10.1016/j.pacfin.2014.10.001.

Hansen, C., Hausman, J. and Newey, W. (2006), "Estimation with many instrumental variables", Journal of Business and Economic Statistics, Vol. 26 No. 4, pp. 398-422.

Majid, M.S. and Kassim, S. (2010), "Potential diversification benefits across global Islamic equity markets", Journal of Economic Cooperation and Development, Vol. 31 No. 4, pp. 103-126.

Miniaoui, H., Sayani, H. and Chaibi, A. (2015), "The impact of financial crisis on Islamic and Islamic equities and COVID-19 pandemic conventional indices of the GCC countries", The Journal of Applied Business Research, Vol. 31 No. 2, pp. 357-370.

Pesaran, M.H., Shin, Y. and Smith, R.J. (1996), "Testing for the existence of a long-run relationship", Working Paper No. 9622, Department of Applied Economics, University of Cambridge, Cambridge.

Phan, D. and Narayan, P.K. (2020), "Country responses and the reaction of the stock market to COVID-19-A preliminary exposition”, Emerging Markets Finance and Trade, Vol. 56 No. 10, pp. 2138-2150, doi: 10.1080/1540496X.2020.1784719.

Pindyck, R.S. and Rubinfeld, D.L. (1998), Econometric Models and Economic Forecasts, Irwin/McGrawHill, Boston.

Rizvi, S.A. and Arshad, S. (2014), "An empirical study of Islamic equity as a better alternative during crisis using multivariate GARCH DCC”, Islamic Economic Studies, Vol. 22 No. 1, pp. 159-184.

S\&P (2020), "Islamic finance 2020-2021: COVID-19 offers an opportunity for transformative developments", available at: https:/www.spglobal.com/ratings/en/research/articles/200615islamic-finance-2020-2021-covid-19-offers-an-opportunity-for-transformative-developments11533355 (accessed 19 August 2020).

Saâdaoui, F., Naifar, N. and Aldohaiman, M.S. (2017), "Predictability and co-movement relationships between conventional and Islamic indexes: a multiscale exploration using wavelets", Physica A: Statistical Mechanics and its Applications, Elsevier, Vol. 482, pp. 552-568, doi: 10.1016/j.physa. 2017.04.074.

Saiti, B., Bacha, O.I. and Masih, M. (2014), "The diversification benefits from Islamic investment during the financial turmoil: the case for the US-based equity investors", Borsa stanbul Review, Vol. 14 No. 4, pp. 196-211.

Stock, J.H., Wright, J.H. and Yogo, M. (2002), “A survey of weak instruments and weak identification in generalized method of moments", Journal of Business and Economic Statistics, Vol. 20 No. 4, pp. 518-529.

Waheed, R., Sarwar, S., Sarwar, S. and Khan, M.K. (2020), "The impact of COVID-19 on Karachi stock exchange: quantile-on-quantile approach using secondary and predicted data", Journal of Public Affairs, Vol. 20 No. 4, pp. 237-253, doi: 10.1002/pa.2290"10.1002/pa.2290.

Yarovaya, L., Elsayed, A. and Hammoudeh, S. (2020), "Searching for safe havens during the COVID-19 pandemic: determinants of spillovers between Islamic and conventional financial markets", available at: https://ssrn.com/abstract=3634114 (accessed 13 August 2020).

Yusof, R.M. and Majid, M.S. (2007), "Stock market volatility transmission in Malaysia: Islamic versus conventional stock market”, Journal of King Abdulaziz University: Islamic Economics, Vol. 20 No. 2, pp. 17-35.

Zaremba, A., Kizys, R., Tzouvanas, P., Aharon, D.Y. and Demir, E. (2020), "The quest for multidimensional financial immunity to the COVID-19 pandemic: evidence from international stock markets", available at: https://ssrn.com/abstract=3632466 (accessed 12 August 2020).

\section{Further reading}

Abdulkarim, B., Linn, J.F. and Abdulkarim, Z. (2017), "Determinants of the Islamic stock markets integration”, Accounting and Finance Research, Vol. 6 No. 3, pp. 147-152. 
IES

29,1

Aggarwal, R., Kearney, C. and Lucey, B. (2012), "Gravity and culture in foreign portfolio investment", Journal of Banking and Finance, Vol. 36 No. 2, pp. 525-538.

Asutay, M. (2012), "Conceptualising and locating the social failure of Islamic finance: aspirations of Islamic moral economy vs. the realities of Islamic finance", Asian and African Area Studies, Vol. 11 No. 2, pp. 93-113.

Atly, A. (2015), "Islam as a catalyst for economic integration? The case of the developing-eight", available at: $\mathrm{http} / /$ www.ayk.gov.tr/wp-content/uploads/2015/01/ATLI-Altay-ISLAM-AS-ACATALYST-FOR-ECONOMIC-INTEGRATION-THE-CASE-OF-THE-DEVELOPING-EIGHT. pdf (accessed 12 March 2019).

Bayoumi, T., Fazio, G., Kumar, M. and MacDonald, R. (2007), "Fatal attraction: using distance to measure contagion in good times as well as bad", Review of Financial Economics, Vol. 16, pp. 259-273.

Choudhury, M.A. (2001), "Islamic venture capital: a critical examination", Journal of Economic Studies, Vol. 28 No. 1, pp. 14-33.

Engle, R.F. and Granger, C.W.J. (1987), "Cointegration and error correction: representation, estimation and testing”, Econometrica, Vol. 55 No. 2, pp. 251-276.

Flavin, T.J., Hurley, M.J. and Rousseau, F. (2002), "Explaining stock market correlation: a gravity model approach", The Manchester School Supplement, Vol. 70, pp. 87-106.

Granger, C.W.J. (1969), "Investigating causal relations by econometric and cross-spectral methods", Econometrica, Vol. 37, pp. 424-438.

Greene, W.H. (2003), Econometric Analysis, Prentice-Hall, New Jersey, NJ.

Huang, J. and Brahmasrene, T. (2006), "Measuring emerging stock market correlations utilizing the gravity model", Journal of Economics and Economic Education Research, Vol. 7 No. 3, pp. 71-86.

Lucey, B.M. and Zhang, Q. (2009), "Does cultural distance matter in international stock market comovement? Evidence from emerging economies around the world", Emerging Markets Review, Vol. 11, pp. 62-78.

Mishra, B.R. and Jena, P.K. (2019), "Bilateral FDI flows in four major Asian economies: a gravity model analysis", Journal of Economic Studies, Vol. 46 No. 1, pp. 71-89.

Padaki, R. and Goel, M. (2015), "A gravity model analysis of effects of regional economic integration on factor flows", Journal of Economic Cooperation and Development, Vol. 36 No. 4, pp. 121-144.

Tinbergen, J. (1962), Shaping the World Economy, Twentieth Century Fund, New York, NY.

Zainal abidin, I.S., Abubakar, N. and Sahlan, R. (2013), "The determinants of exports between Malaysia and the OIC member countries: a gravity model approach", Procedia Economics and Finance, Vol. 5, pp. 12-19.

\section{Corresponding author}

Shafiu Ibrahim Abdullahi can be contacted at: shafiuibrahim@gmail.com

For instructions on how to order reprints of this article, please visit our website:

www.emeraldgrouppublishing.com/licensing/reprints.htm

Or contact us for further details: permissions@emeraldinsight.com 